CATALAN REVIEW

Catalan Review

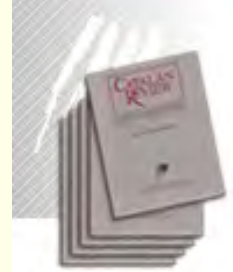

You are accessing the Digital Archive of the Catalan Review Journal.

By accessing and/or using this Digital Archive, you accept and agree to abide by the Terms and Conditions of Use available at http://www.nacs-

catalanstudies.org/catalan review.html

Catalan Review is the premier international scholarly journal devoted to all aspects of Catalan culture. By Catalan culture is understood all manifestations of intellectual and artistic life produced in the Catalan language or in the geographical areas where Catalan is spoken. Catalan Review has been in publication since 1986 .
NORTH

AMERICAN

CATALAN

SOCIETY
Esteu accedint a l'Arxiu Digital del Catalan Review

A l' accedir i / o utilitzar aquest Arxiu Digital, vostè accepta i es compromet a complir els termes i condicions d'ús disponibles a http://www.nacs-

catalanstudies.org/catalan review.html

Catalan Review és la primera revista internacional dedicada a tots els aspectes de la cultura catalana. Per la cultura catalana s'entén totes les manifestacions de la vida intel lectual i artística produïda en llengua catalana o en les zones geogràfiques on es parla català. Catalan Review es publica des de 1986.

\title{
Intercomprehension and Catalan: The EuroCom Project Esteve Clua
}

Catalan Review, Vol. XXI, (2007), p. 151- 173 


\title{
INTERCOMPREHENSION AND CATALAN: THE EUROCOM PROJECT*
}

\author{
ESTEVE CLUA
}

\section{ABSTRACT}

This paper presents a method to teach intercomprehension (a strategy for simultaneous learning of receptive capacities in languages that belong to the same linguistic family) as a means for strengthening multilingualism in order to overcome communication problems generated by the growing need for interrelationships, without having to forsake language diversity. The paper introduces EuroCom, an intercomprehension project involving three large European linguistic families (Slavonic, Germanic, and Romance), and describes its methodology and strategies for learning. The article stresses the importance of intercomprehension for languages like Catalan as a strategy to truly promote the respect for linguistic diversity at the European and Spanish levels.

El preu de la intercomprensió linguíística mundial no ha de ser pas la renúncia de tots els grups lingüístics a la seva llengua pròpia, excepte en el cas del que tingui la sort que la seva llengua sigui la triada com a instrument de relació general. El que cal és intentar assegurar un equilibri lingüístic sostenible per a la gran majoria de grups humans, tot tenint com a centre les persones.

La gran qüestió torna a ser com s'hauria d'organitzar idealment una espècie lingüísticament diversa, però que se sap única i es vol unida i fraternal. I en el fons de la qüestió, hi ha el fet de com s'hauria de dur a terme una 'justícia medioambiental' també per al pla lingüístic. (Bastardas, Sostenibilitat 6I)

\section{HUMAN INTERCOMMUNICATION IN A NEW SOCIOLINGUISTIC CONTEXT}

$\mathrm{O}$ ne of the features that best explains the world today is diversity, not only in the environment but also in languages. In theory, and from the point of view of nature, diversity is generally seen as enriching. An increasing number of people are concerned with striking an ecological

This study has received support from the Spanish Ministry of Science and Technology (research project HUM2004-01504/FILO) and the FEDER ('Fondo Europeo de Desarrollo Regional'). Some parts of the study were presented at the XIV Colloquium of the International Association of Catalan Language and Literature (Budapest, September 2006). 
balance for natural systems and spaces that will allow that diversity to continue. In the human sphere, however, it is not so clear, and still less when dealing with the language issue. Although it is usually taken for granted that the cultural and linguistic diversity of the world is a priceless historical heritage that deserves to be conserved, the difficulties diversity causes in intercommunication between the different groups that make up the human race tend to tip the balance towards a negative assessment of the phenomenon. Indeed, the attitude of humanity to the question of language diversity and the problems of communication it may cause has swung between two opposing views: the first sees this situation as negative and tries to overcome it with monolingualism (predominant use of a single language) or oligoglossia (predominant use of a few languages), whereas the second view regards the multilingualism of humanity as something intrinsically positive, a wealth that must be preserved. ${ }^{\mathrm{Y}}$

The (apparent) clash between the maintenance of language diversity as the heritage of all humanity and the needs for intercommunication between groups with different languages has been with the human race throughout history, but today it is increasingly tangible for a larger number of people and language communities. The imperious need to know other languages, which was formerly a feature of communities with minority languages, is now experienced in a new sociolinguistic context by many other communities with national or central languages. There is a wide range of reasons for this new sociolinguistic situation. One of them, at least in the case of the less economically and technologically developed zones, has to do with the set of processes knows as globalization, which has brought about a considerable rise in the possibilities of interrelation between people belonging to different language groups. On the one hand, the expansion of the traditional market areas means knowing new languages to be able to deal with new traders who belong to different language communities. On the other, satellite and internet communications allow us to see broadcasts and be in daily contact with people and contents from faraway places, which have frequently been produced in languages other than the receivers'. Another reason for this new sociolinguistic context, to a large extent related to the previous one, is the emergence of new spheres of suprastate political organization, which usually occur across continents. A clear example is the process of European integration, which goes beyond the economic sphere and touches on

\footnotetext{
'Moreno Cabrera (59-62) argues that these two positions are related to the biblical myths of the Tower of Babel and Pentecost, the first as a starting point for the negative view of language diversity; and the second as the overcoming of that negative view through intercomprehension.
} 
politics and culture. The creation of the European Union means a need to ponder, along different lines from the usual ones within the member states so far, some way of overcoming the difficulties that arise from the interrelation and intercommunication of a considerable number of European communities which have different languages.

Thus, the European context is experiencing a considerable expansion of the classic areas of human communication, which had so far allowed many communities to remain completely monolingual. At the same time, for many individuals, this extension of the zones and spheres of interrelation has meant a need to give up monolingualism in order to develop fully. For small languages like Catalan this new situation raises the possibility that once contacts between different language communities have multiplied and far more people are affected by the apparent deadlock between language diversity and intercommunication, there may be a rethink of the way interlinguistic communications in the different spheres (from global to local, by way of suprastate, state, and regional) have been predominantly organized so far. In other words, what is proposed is a more harmonious organization of the interrelation between the different human language groups from, not against, language diversity.

The issue is extremely complex; no doubt as complex as humanity itself. But what seems clear, and to an increasing number of people, is that one of the basic strategies for increasing intercommunication between different language groups, without losing the wealth of the language diversity created by humanity over centuries, is to promote multilingualism, effectively and on a huge scale. ${ }^{2}$ In fact, however, what often happens is that this necessary promotion of multilingualism is confined to learning English, which has become the language of international communication. And so, as long as there is no fairer planetary language policy, there are more and more people who see English as a practical solution to their needs for intercommunication with other groups, whether close linguistically (belonging, for example, to the same language family), or speaking quite different languages.

\section{MULTILINGUALISM AND INTERCOMPREHENSION}

In the European Union, the situation, at least on paper, is quite different. In theory, there is an intention to develop a language policy that tends towards the preservation of the cultural and linguistic

'See a sample in Bastardas (Politica), an analysis of this issue from the perspective of complexity. 
wealth of the states that make it up, as a symbol of European identity, As a result, although on the one hand English is promoted as the language of global communication, on the other a series of functions for the languages of the different member states of the Union are maintained. In the end, it is a matter of establishing a series of counterweights to the excessive preponderance of the lingua franca. And so in the field of education the more or less realistic aim is for as many pupils as possible to learn at least two modern languages (one of which is usually English) in addition to their mother tongue. The point, then, is to prevent the learning of English at school from consuming all the efforts put into language learning.

Given that achieving a widespread active multilingualism beyond two or three languages does not seem a very realistic goal, it might be advisable to lower the sights on the side of the type of multilingualism, so as not to give up multilingual communication. In other words, for people who speak different languages to be able to communicate it is not indispensable for them to have a mutual active competence in all of them; it is enough for them to master their receptive competences in the languages of their interlocutors. This differentiation between active (speaking and writing) and receptive (understanding and reading) competences is fundamental for fostering multilingual intercommunication, since receptive multilingualism, or intercomprehension, is far more realistic because it requires less effort and less learning time, especially when it comes to learning languages genetically related to the learner's.

Along this line, with the creation of the Common European Framework of Reference for Languages: Learning, Teaching, Assessment guidelines for the international comparison of objectives and qualifications in language learning and teaching to facilitate personal and vocational mobility in Europe providing a valuable tool for policy making, the Council of Europe has opened the doors to the need to complement productive competence in two modern languages, desirable for all young Europeans, with receptive competences in other languages. That means that the European institutions are also promoting the educational option of intercomprehension as a way of overcoming the problems of communication between Europeans.

Intercomprehension means the capacity to understand a foreign language without having learned it from its similarities to the mother tongue or another language. From a communicative point of view, the

${ }^{3}$ Another matter is whether the states want to preserve the cultural and linguistic wealth of the different groups that make them up. That is the case, for example, of Spain, where the Constitution clearly gives preferential treatment to the Spanish language and discriminates against the others. 
concept of intercomprehension refers to the communication that takes place between interlocutors who are each speaking their own language. Examples of communication between different language communities by means of intercomprehension are not at all unusual. In the context of Europe, the case usually referred to as a paradigm of intercomprehension is that of the Scandinavian countries with Germanic languages (Denmark, Norway, and Sweden), where practice regarding differences and similarities among languages at school has provided students with receptive competence in several languages. But intercốmprehension is also used among different varieties of Mandarin Chinese or language varieties of Western Africa. In the end, intercomprehension also occurs to different degrees between varieties of the same language (e.g., between someone from Barcelona and someone from Mallorca).

For many Europeans, communication through a third language, a lingua franca, cannot satisfy their desire to deepen the increasingly frequent and necessary contacts with other Europeans, since in this case no one is speaking their own language; from a linguistic point of view, no one is really meeting the other. Europeans are increasingly aware of the importance of respecting other people's languages. Umberto Eco (355), one of the first defenders of receptive multilingualism, puts this idea of communicative intercomprehension between Europeans in a nutshell:

Una Europa di poliglotti non è una Europa di persone che parlano correntemente molte lingue, ma nel migliore dei casi di persone che possono incontrarsi parlando ciascuno la propria lingua e intendendo quella dell'altro, che pure non saprebbero parlare in modo fluente, $e$ intendendola, sia pure a fatica, intendessero il "genio", l'universo culturale che ciascuno esprime parlando la lingua dei propri avi e della propria tradizione.

For some years, but in particular during the last decade of the last century, a new discipline has been taking shape in the sphere of European foreign language teaching known as third language learning research. It is a discipline that defends the systematic use of the competences acquired in other foreign languages for the learning of a third, fourth or fifth. Over the same period and mainly in Europe, a new discipline has begun to develop which focuses on the study of methods designed for the acquisition, not of a third language but of different ones simultaneously. This is what is known as the teaching of simultaneous language learning. It is a methodology that may mean a major saving of time and intellectual effort when applied to the learning of similar languages (from the same family). It must be borne in mind that in theory the learning goals pursued with these methods only cover reading comprehension and in some cases oral comprehension as well. 
These two disciplines are at the base of intercomprehension, which, with the support of the European institutions, has undergone a remarkable development in recent years. ${ }^{*}$ Among the most important European intercomprehension projects are: EuroCom, Eurom 4 , Galatea-Galanet, and IGLO (Intercomprehension in the Germanic Languages Online). 5

\section{EUROCOMPREHENSION: THE EUROCOM PROJECT}

EuroCom is the name of a European project on intercomprehension which involves a large number of researchers, with the shared aim of offering Europeans who have a good knowledge of a Slavonic, Germanic or Romance language an intercomprehensive method for having easy access to others of the same family. The aim of the EuroCom project is to promote multilingualism through receptive language competences (reading, first of all) without demanding an excessive extra effort. As a basic strategy it uses cognitive exploitation of the kinship between the languages of a family or group. At present, it is being applied simultaneously to the three great families of European languages: EuroComRom for the Romance languages, EuroComGerm for the Germanic ones, and EuroComSlav for the Slavonic languages. Another branch of the project, EurocomDidact, focuses on research into the teaching and learning of multilingualism and intercomprehension. ${ }^{6}$ Lastly, the opening of the EuroComCenter provides an opportunity to accede to courses on Eurocomprehension via internet.

The most developed branch of the project is the Romance language one. In 2000, Die sieben Siebe: Romanische Sprachen sofort lesen Könen (Klein and Stegmann) was published, the first manual for the intercomprehension of Romance languages, designed for German students with a good knowledge of French. In this case, the target languages were Catalan, Spanish, French, Portuguese, and Romanian. Later, the work was adapted for Romanian (Reinheimer et al.), Italian (Giudicetti et al.), Portuguese (Göttsche et al.), Catalan (Clua et al.), English (McCann et al.), French (Meissner et al.), Polish (GalinskaInacio et al.), and Spanish (Martín Peris et al.). In the latest adaptations, other languages such as Galician and Occitan have also been added.

+ See, for example, Kischel, a compilation of the contributions on intercomprehension in the different European language families.

5 The references on the internet for these projects are: EuroCom <www. eurocomprehension.info>, Galanet <www.galanet.be>, <http://galanet.free.fr>, and IGLO project <www.hum.uit.no/a/svenonius/lingua/index.htmls.

${ }^{6}$ Meissner (7-140) provides an introduction to the teaching of intercomprehension. 
One remarkable aspect of the EuroComRom project is that, unlike other Romance intercomprehension projects, it has been consistent with its multilingual ideology from the outset in the sense of valuing multilingual situations positively (Moreno Cabrera 80) and promoting equality, and it has not restricted itself to working only with the Romance languages with the most speakers (Spanish, French, Italian, and Portuguese). On the contrary, from the first intercomprehension manual (Klein et al.), EuroComRom has taken into account languages which are quantitatively less powerful, such as Catalan and Romanian. From the point of view of Catalan, that initial rejection of the oligoglossic ideology, understood as "an ideology that justifies and promotes the imposition of a small number of languages on different multilingual communities" (Moreno Cabrera 80), is very important, since it has meant that Catalan has been the object of European intercomprehensive learning from the beginning.

\section{Methodology}

EuroCom is based on the principle that language learning is easy provided the languages belong to the same family as the learners' own language or another they know well, and on the fact that the speaker of a language already knows many things about the other languages of the same family before beginning to learn. In other words, although one may never have studied them, one knows many things about Romance languages. Language learners have a large amount of previous knowledge that supplies them, for example, with a considerable level of textual comprehension. It is only a matter of knowing how to recognize, how to discover all those items of previous knowledge of the language or languages being learned. This discovery process rests on two linguistic bases:

a) The similarities existing between the languages of the same family in the different linguistic (phonological, morphological, lexical, syntactic, and semantic) and cultural spheres.

b) International lexis, with a common base in broad sectors of modern life and specialized language.

The first base has priority because, beyond the lexis, it allows us to recognize known structures in the new language, in phonology, morphology, syntax and semantics.

This process of discovery takes advantage of the human ability to transfer experiences, known structures and meanings to new contexts. EuroCom trains learners to make systematic use of that ability in the 
transition to a new language. In the end, the teaching of intercomprehension is basically transferential; it is fundamentally a matter of transferring the knowledge everyone has about the structure and lexis of their own language (or of another or others they know) to the new languages they learn, while establishing hypotheses about the grammatical functioning of these new languages. That is why in intercomprehensive learning the more languages one knows the easier it is to establish hypotheses about the functioning of a new one. Likewise, discovering the correspondence of a word in the source language with a word in a second one may smooth the way to comprehension of the correspondence in a third, more distant one, e.g., Spanish curarlguarecer $>$ Catalan guarir > French guérir, hence, the importance of simultaneous work with a large number of genetically related languages.

In this type of learning methodology, interlinguistic comparison plays a fundamental role. The process of comparing is at the base of the establishment of hypotheses about the grammar of the target languages, but to be efficient it has to be activated directly by the learner and not imposed by the method or the teacher, since otherwise the effects on the improvement of the capacity for establishing successful deductive hypotheses would not be obtained.?

Figure $x$ shows the process for the intercomprehension of written texts (Klein et al.), that is, the different mental activities that allow the reader to identify the textual content in relation to the seven sieves, which are the bases for establishing the correspondences between the known language(s) and the ones to be learned.

According to the model, the classes in which this methodology will be applied will take the following steps. First, before beginning to read a text, learners must be aware that they have previous knowledge that can help them understand the text, because every text is situated in a particular context and reality. In the case of Europe, a common sociocultural context that affects contemporary geography and history can be taken for granted (e.g., the Graeco-Roman and Christian heritage). The cognitive referent of a text unit is the base from which expectations are created about the content, expectations that help the reader to decipher it, in the form of a hypothesis about its development. The form and the support of the publication also generate previous expectations. The reader can easily grasp whether it is a journalistic text, a literary work, an administrative document, or a piece of technical writing. All those elements, which are used

\footnotetext{
? See Meissner's (18-27) proposals for the grammar of hypothesis and the Multilingual Didactic Monitor.
} 


\section{FIGURE 1}

OPTIMIZED DEDUCTION MODEL (ADAPTED FROM KLEIN ET AL.)
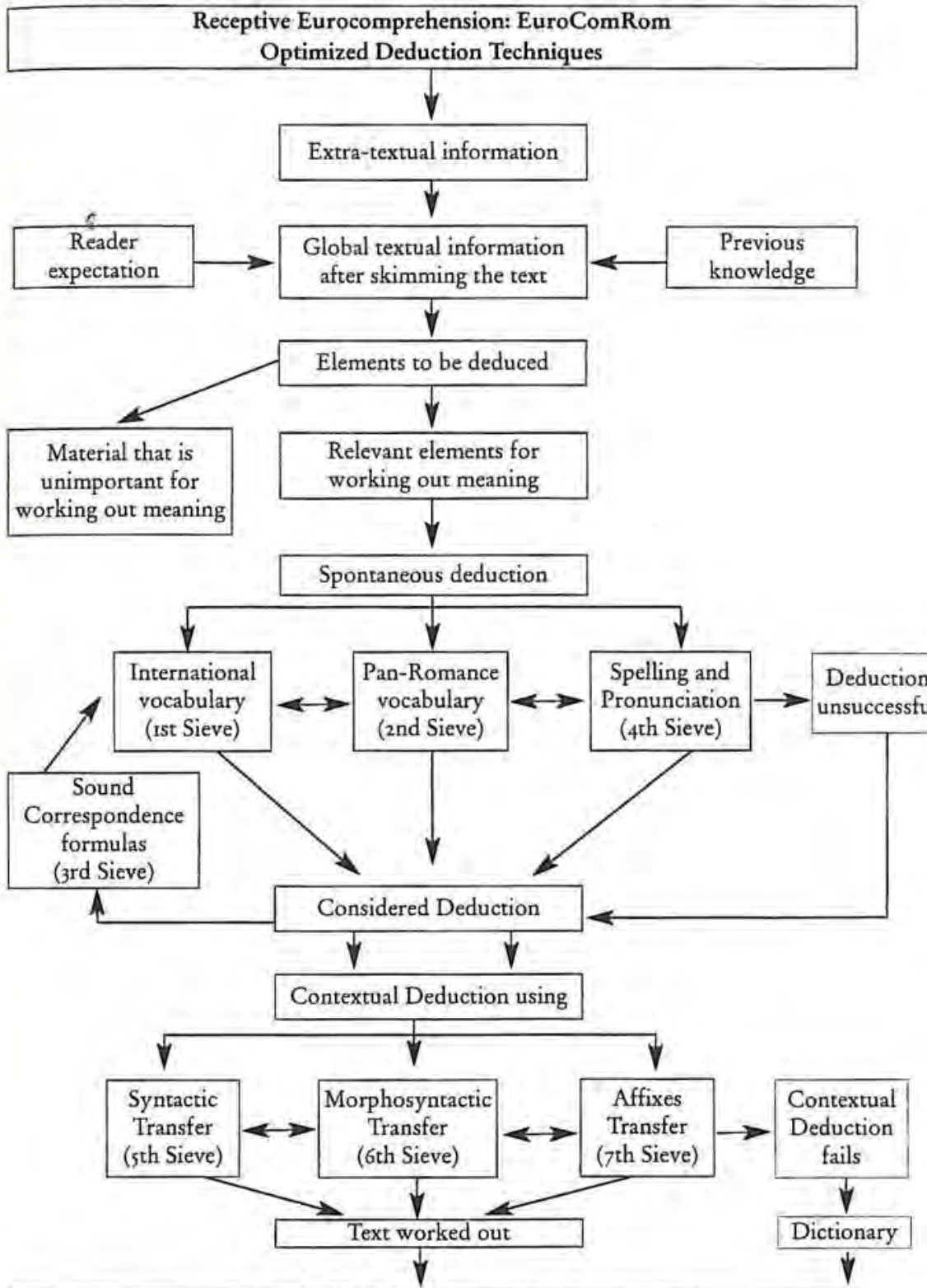
completely automatically in the mother tongue, must be applied consciously and with particular skill when it comes to reading texts in a new language.

If there is a title and subtitle that can be easily understood, it is advisable to try to mark out the subject and imagine what a text referring to it might be like. Next comes a first rapid reading of the text or the paragraphs that seem most important; for instance, the first and the last. After that first reading, the global content of many texts will be perfectly comprehensible. As for more difficult ones, the most advisable strategy may be not to read word by word, skip obstacles, not to feel tied by the position of the words, not to worry about unknown grammatical details, not to look words up in a dictionary, and not to become blocked. Next, the reader determines the general topic and the main ideas and tries for a broad grasp of the purpose of the text and the tone used by the author.

The next step is to translate all the known words with the help of the international vocabulary and the Pan-Romance vocabulary. In the next reading, readers fill in the gaps and they use the logic of the context to mark out the possible contents of the blank spaces. The elements of the sentences that the reader has already understood clarify the meaning of the ones still waiting to be deciphered. A particular subject restricts the possible verbs that can go with it, e.g., un bélicoptère (French) 'takes off,' 'flies,' 'lands,' or 'falls.' Likewise, the reader can make hypotheses about the possible complements or objects of a verb. The comprehension of a noun makes it unnecessary to understand the adjective that goes with it exactly, e.g., une publication hebdomadaire (French) 'a weekly publication.' Similarly, comprehension of an adjective sheds some light on a noun that the speaker may not have understood, e.g., une chaleur tropicale (French) is evidently something 'tropical,' or a gheppio coraggioso (Italian), 'something that has courage,' from the similarity of the adjectives. In these cases, the adjective can be made into a noun and at first can serve to fill in for the missing one. Finally, the verbs that cannot be understood can be adapted initially to Catalan verb endings: spaventare (Italian) > 'spaventar' > espantar. The nouns that are difficult to relate to anything can be temporarily translated by words adapted to the speaker's own language, or even jokers of the "whatsit" type. A final reading will enable the speaker to deduce new words from the general context and enable a better comprehension of the text.

Having reached this point, readers should be satisfied with the comprehension or quasi-comprehension that they have achieved and dare to "live with the gaps." Instead of being obsessed with perfectionist concerns, learners should admire the degree of 
comprehension they have reached without any learning effort. They can enjoy the confirmation that in the new language, apparently unknown until now, it is possible to make correct suppositions about broad segments of text. Moreover, they can trust in the prospect of reaching an increasingly broad comprehension as they read more texts. At later stages of reading, they can satisfy their curiosity by looking up the words they have been unable to deduce with this strategy in a bilingual dictionary.

It is also crucial for students, in order to improve their intercomprehension and general learning capacities, to think about the processes they have used to identify a particular form or deduce its meaning. They must be aware of the attitudes, techniques, or strategies that have allowed them to make progress with their intercomprehension.

\section{The Seven Sieves}

EuroComRom systematizes the spheres in which one can recognize known elements of each new language in seven sectors, called The Seven Sieves. These Seven Sieves are the bases from which the learners can establish the necessary correspondences between their language and the languages being learned so that they become transparent from the point of view of comprehension. Metaphorically, in seven sieving processes, learners -like the gold prospector-extract everything that belongs to them from the new language. This systematic subdivision of the elements that intervene in intercomprehension into seven spheres springs from methodological requirements. The process of comprehension is difficult to segment into seven subprocesses, but this allows the learner to better grasp each of the particular spheres that come together in the comprehension of the text.

The complexity of the understanding process merely reflects part of the complexity of language. Just as the linguist faces this complexity by segmenting a languages grammar into different components (lexis, morphology, syntax, phonology, and so on) the EuroCom project does the same with the process of intercomprehension. In fact, the seven sieves are very closely related to the components that make up the grammar (or the knowledge that a speaker has) of a language. The first two focus on the lexical component, and work is done on internationalisms, i.e., words shared by most languages today, and also on Pan-Romanic lexical items. The third sieve makes it possible to recognize phonic changes undergone by words shared by Romance languages. The fifth sieve analyzes the syntactic resemblances of the languages that are essential for understanding. The sixth and seventh 
sieves describe basic aspects of inflective and derivative morphology, respectively. And finally, the fourth sieve describes the similarities and differences in the graphic representation of the Romance languages.

\section{First Sieve: International Vocabulary}

With the first sieve, learners extract the international lexis from the new language. This is a set of words that has been created in the standard varieties of many modern languages as a result of the development of modern life and human thought. This vocabulary, which is shared to different degrees by the different languages, has a largely Latin base. An adult has about 5000 words of this type (cigarette, pharmacy, liberalism, humor), which can be recognized in other languages with no effort, because they are generally found with few modifications (Table $\mathrm{r}$ ):

TABLE I

INTERNATIONAL VOCABULARY IN ROMANCE LANGUAGES

\begin{tabular}{|c|c|c|c|c|c|}
\hline Catalan & French & Italian & Porruguese Romanian & Spanish & English \\
\hline & & & & & \\
\hline
\end{tabular}

The abundance of internationalisms is a common feature of texts in the fields of'science, sports, new technology, or international politics, among others. That makes comprehension of this type of texts much easier. The following extract (I) contains a newspaper article about international politics in a language, Romanian, linguistically very distant from the other Romance languages:

\section{"Interesele economice apropie SUA şi UE"}

Europenii au cerut eliminarea vizelor americane pentru nou-venitii in Uniune Lideri europeni şi americani s-au reunit, ieri, la Casa Albă, în cadrul summitului Uniunea Europeană - Statele Unite, în speranţa întăririi cooperării economice şi a găsirii unor soluții pentru combaterea terorismului. Europenii au cerut, de asemenea, eliminarea vizelor pentru cetătenii din toate cele 27 de ţări membre. O problemă sensibilă, cea a încălzirii globale, $n u$ a fost discutată decât adiacent, deoarece președintele George W. Bush $n u$ acceptă stabilirea unor plafoane privind emisiile de ggze, invocând interesele economiei naționale americane. 
In this case, the profusion of proper nouns (Uniunea Europeană, Statele Unite, George W. Bush) and internationalisms (in italics) makes comprehension of the global meaning of the text easier. Even though one may hardly know Romanian, one can deduce that the article refers to a summit between the European Union and the United States about economic cooperation and the struggle against terrorism; one can also gather that President Bush does not accept something about the emission of gases, invoking American economic interests.

As for international vocabulary, the Romance group has the greatest advantage, since a large number of these words come from Romance languages and Latin (probably more than $90 \%$ ). For that reason, the first sieve is hardly important for the learning of a Romance language from any of the others. Its value, however, is considerably enhanced when it comes to learning one of them from a language belonging to another family.

\section{Second Sieve: Pan-Romance Vocabulary}

In addition to the international vocabulary, each language family has a particular vocabulary that differentiates it from the other language groups. In the case of the Romance languages, this is what is called Pan-Romance Vocabulary. It contains the words derived almost entirely from Latin that are still used today in all or most Romance languages. This sieve shows how knowledge of a single Romance language is an open door to the other ones. About 500 Latin words are found today in the basic vocabulary of most of the Romance languages. The Pan-Romance Vocabulary consists mostly of words that belong to the basic, and often the most frequent, vocabulary in each of the languages (Table 2):

TABLE 2

PAN-ROMANCE VOCABULARY

\begin{tabular}{lllllll}
\hline Catalan & Spanish & French & Italian & Portuguese & Romanian & English \\
\hline lluna & luna & lune & luna & lua & lună & 'moon' \\
pa & pan & pain & pane & pão & pâine & 'bread' \\
pedra & piedra & pierre & pietra & pedra & piatră & 'stone' \\
sang & sangre & sang & sangue & sangue & sânge & 'blood' \\
\hline
\end{tabular}




\section{Third Sieve: Sound Correspondences}

In the previous spheres, it is often easy to recognize words from the other Romance languages in Catalan (e.g., Romanian diplomatit 'diplomats,' Italian vini 'wines'), whereas in other cases one needs to take several steps to deduce the Romanian word (e.g., Romanian peste $>$ Italian pesce > Catalan peix 'fish.' That is due to the fact that as languages have evolved some words have undergone very few phonic or graphic changes, whereas others have undergone considerable ones. This third sieve provides the learner with the necessary resources to better grasp the changes undergone by some words and to recognize the lexical kinships that cannot be seen at first glance. Just a few formulae are necessary to easily attain knowledge of the correspondences between the sounds of the different languages as they are today. And so, with no great learning effort - starting in each case from an example (if nuit in French corresponds to nit in Catalan, to noite in Portuguese, to notte in Italian, and to noche in Spanish; so Ilet, leite, latte, and leche correspond to the French lait) - one can immediately see a series of historical modifications and recognise the word in its different forms (Table 3):

TABLE 3

EVOLUTION OF INITIAL CONSONANT CLUSTERS PL, BL, FL, AND CL IN ROMANCE

\begin{tabular}{|c|c|c|c|c|c|c|c|}
\hline & Catalan & French & Iralian & Port & Rom & Spa & Engl \\
\hline \multirow[t]{2}{*}{ PL } & ple & plein & pieno & che & plin & Hleno & 'full' \\
\hline & pla & plaine & piano & chão & plan & Hlano & 'flat' \\
\hline BL. & blasmar & blâmer & biasimare & lastimar & blestema & lastimar & 'blame' \\
\hline \multirow[t]{2}{*}{ FL } & flama & flamme & fiamma & chama & & llama & 'flame' \\
\hline & flor & fleur & fiore & flor & & flo & \\
\hline $\mathrm{CL}$ & clau & clé, clef & chiave & chave & cheie & llave & 'key' \\
\hline
\end{tabular}

\section{Fourth Sieve: Spelling and Pronunciation}

The fourth sieve refers to graphic signs and pronunciation. In the Romance languages, although the same signs are used to represent most of the sounds, some spellings are different in each case and make it difficult to recognize the lexical correspondences. By way of example, among the vowels the French $[\mathrm{u}]$ is written ou and the one written as $u$ is pronounced [y], which is equivalent to the German sign 
\#̈. As far as the consonants are concerned, the Western Romance languages represent the sound $[\mathrm{k}]$ before $e$ and $i$ with $q u$, whereas the Eastern ones use the sign $c h$. The sign $c h$ is used in French and Portuguese for the sound [J], and in Spanish for the sound [t]]. The sound [T] is written in Italian and Romanian $c e$ or $c t$; i.e., $c$ before $e$ and $i$. Other examples of different signs to represent the same sound are $g u$ and $g h$ for the sound [g] before the vowels $e$ and $\dot{r}$, the signs $l l, l h$, and $g /$ for the palatal lateral $[K]$, and the signs $g n, n, n h$, and $n y$ for the palatal nasal [n] (Table 4). The case of palatal sounds is definitely the most Eomplicated one in the Romance graphic system, but it should not create too many problems: once the learners know that che in Italian is pronounced like que in Catalan, they can easily recognize the Catalan conjunction que. Once they have grasped that $-c i$ is pronounced [T] in Romanian (in the end position of the word; in other positions [ [ [ $[1]$ ), they can associate the word meci with a (football) match through the pronunciation [mæt]], especially in a sporting context.

\section{TABLE 4}

REPRESENTATION OF THE PALATAL NASAL [ $\Omega$ ]

\begin{tabular}{lllllll}
\hline Catalan & French & Italian & Portuguese & Romanian & Spanish & English \\
\hline senyor & seigneur & signore & senhor & senior & señor & 'sir' \\
\hline
\end{tabular}

\section{Fifth Sieve: Pan-Romance Syntactic Structures}

The fifth sieve focuses on the fact that to a large extent the Romance languages share the basic (Pan-Romance) syntactic structures. Anyone who is aware of this can immediately appreciate that knowledge of the syntax of a single Romance language can be of great help with all the others to locate the position of articles, nouns, adjectives, verbs, conjunctions, etc. For example, the Romanian copulative conjunction $s i$ is not very transparent from the point of view of the other Romance languages, but in structures like the one in (2) it is easy to recognize it.

\section{(2) Lideri europeni și americani...}

Estonia, Letonia, Lituania, Slovacia și Slovenia se numără printre tările...

On the basis of this high degree of syntactic parallelism, one can isolate the peculiarities of particular languages and make them comprehensible with brief indications. See in (3) an example of the conditional sentences that use the introductory particles: $s i, s e$, and dacă. 
(3) Catalan: En Pere és feliç, si pot dormir a l'oficina.

French: $\quad$ Pierre est heureux, si il peut dormir dans le bureau.

Italian: Pietro è felice, se può dormire in ufficio.

Portuguese: Pedro fica feliz, se pode dormir no escritório.

Romanian: Petre este fericit, dacă poate dormi la birou.

Spanish: $\quad$ Pedro es feliz, si puede dormir en la oficina.

English: $\quad$ 'Peter is happy, if he can sleep in his office.'

\section{Sixth Sieve: Morphosyntactic Elements}

The previous sieves have shown not only the elements shared by the Romance languages (international vocabulary, Pan-Romance vocabulary, Pan-Romance syntactic structures), but also the specific differences (sound correspondences, spelling, and pronunciation), always with the aim of recognizing the common element that will help transfer knowledge of one language to the others of the same family. In the sphere of morphology too it can be positive to note the common elements through a schematic synthesis. In that way, the learner can learn to recognize the morphosyntactic elements that are common to all Romance languages and to distinguish them from the peculiarities of each one, thus optimizing reading comprehension capacity. With the sixth sieve, EuroComRom provides the learner with the basic rules of morphological elements, with which the different grammatical words or terminations of the Romance languages can be reduced to their common elements. For example, how can one recognize the second person singular of Romance verbs or the plural markers? (Table 5):

TABLE 5

SECOND-PERSON SINGULAR FORMS OF ROMANCE VERBS

\begin{tabular}{llllll}
\hline \multicolumn{2}{c}{ Western Romance languages: -5} & \multicolumn{3}{c}{ Eastern Romance languages: $-\dot{t}$} \\
\hline Spanish & French & Portuguese & Catalan & Italian & Romanian \\
\hline hablas, & tu parles & falas & parles & parli & spui \\
ves & tu vois & vês & veus & vedi & vezi \\
vienes & tu viens & vens & vens & vieni & vii \\
\hline
\end{tabular}

In the Romance languages, the plural markers are clearly recognizable. The Western group is based on the old accusative plural of Latin and marks the plural with $-s$. The Eastern group uses the type of plurat ending in a vowel and differentiate the masculine with $-i$ and the feminine with $-e$, terminations that were characteristic of the nominative plural of the declensions in $-u s$ and in $-a$ of Latin. 
Romanian has ambigens (double gendered words), a legacy of the Latin neuter. These words are always masculine in the singular and feminine in the plural. In this group of nouns, a plural ending based on the Latin model temp-us, temp-ora (Romanian timp, timpurz) has been imposed as a paradigm and is often used to form the plural of neologisms, e.g., botel, boteluri (Table 6).

\section{TABLE 6}

\section{Plural endings in Easter and Western Romance}

Plural endings in Eastern Romance Plural endings in Western Romance languages (vowel ending) languages (ending in $-s$ )

Masculine Feminine Ambigen $(=$ feminine $)$

\begin{tabular}{cccc}
\hline$-i$ & $-e$ & - uri & $-s$ \\
\hline vin-i & montagn-e & vin-uri & vin-s, vin-s, vinho-s, vino-s \\
(Italian) & (Italian) & (Romanian) & (Catalan, French, Portuguese, Spanish) \\
\hline
\end{tabular}

Comparisons such as those in Table 6 make comprehension of the grammatical structures easier. Given that the grammatical units are the ones that appear most frequently in texts, being able to recognize them easily is very useful and profitable for broadening reading comprehension. Moreover, work is also done on idiosyncratic morphological characteristics, such as the enclitic definite article or the existence of morphological case in names in Romanian (4):

(4) Rezultatul referendumului francez reprezintă un eşec pentru procesul

resultat-ul (definite article)

referendum-ul (definite article) -ui (genitive case)

proces-ul (definite article)

Seventh Sieve: Affixes

Lastly, the seventh sieve focuses on affixes. Prefixes and suffixes are recurrent elements in a large number of words. Many of the 3000-5000 verbs each Romance language has on average contain a prefix. However, the number of prefixes and suffixes is small; only about 40 derived from Latin and as many more from Greek have a high productivity; and the number of suffixes that appear widely in each of 
these languages is similar. Today those prefixes and suffixes are largely international. The capacity to separate correctly the affixes from the rest of the word and find out their meaning helps deductive reading considerably. Even if the root of the word is not understood, knowledge of the affix can be a great help to comprehension (Table 7).

\section{TABLE 7}

AFFIXED VERBS IN ROMANCE

\begin{tabular}{|c|c|c|c|c|c|c|}
\hline tala & Fren & Ittalt & $\mathrm{Pc}$ & $\mathrm{Rc}$ & nish & \\
\hline & & & & $\begin{array}{l}\text { a descco } \\
\text { pasaj }\end{array}$ & & \\
\hline
\end{tabular}

\section{Profile words and minigrammars}

After working on all the elements that constitute the bases of transfer in order to understand the other Romance languages, there is a collection of profile words, that is, those idiosyncratic words in each language that are not comprehensible either from another Romance language or through the international vocabulary, or the ones that have modified their meaning to such an extent that not even their etymon helps understand them.

Profile words are formed by the sparse elements that, as peculiarities of the different languages, have escaped the application of the seven sieves (Table 8). They are words that show a heterogeneous distribution throughout the Romance territory. That is explained by the fact that at an earlier stage of the language synonymous forms coexisted but later one of them imposed itself. These divergences can even be found in a particular language; for instance, the different roots of the conjugation of the verb 'to go' in Romance: Catalan anar, Spanish ir, and French aller (infinitive aller, present $j e$ vais, future jirat). In a single lexeme, one finds the whole heterogeneity of the Romance represented, and still more considering that French (as wells as other Romance languages) also has the Romanian variant of 'andare,' in merge, e.g., submerger. 


\section{TABLE 8}

PROFILE IVORDS IN ROMANCE

\begin{tabular}{|c|c|c|c|c|c|c|}
\hline Catalan & French & Italian & Portuguese & Romanian & Spanish & English \\
\hline ceba & oignon & cipolla & cebola & ceapă & cebolla & 'onion' \\
\hline gos & chien & can & $\mathrm{c}^{2}$ & câine & perro & 'dog \\
\hline caure & tomber & cadere & cair, tombar & a cădea & caer & 'fal \\
\hline arribar & arriver & arrivare & chegar & a sosi & llegar & 'arrive' \\
\hline assolir \& & atteindre & attingere & 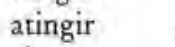 & $a$ at & alcanzar & 'achieve? \\
\hline avet & sapin & abete & $a b$ & br: & abeto & 'spruce' \\
\hline avui & aujourd'hui & oggi & hoje & astăzi & hoy & 'today' \\
\hline començar & commencer & cominciare & começar & a începe & empezar & 'begin' \\
\hline comprar & acheter & comprare & comprar & a cumpăra & $\mathrm{com}$ & 'buy \\
\hline conill & lapin & coniglio & coelho & iepure & conejo & 'rabbit' \\
\hline després & après & dopo & depois & pe urmă & después & 'then' \\
\hline
\end{tabular}

Studying and memorizing profile words is useful to the advanced learner to understand the distribution of Romance vocabulary. They are therefore a tool for refining receptive competence and completing a process that so far had been based on principles of linguistic convergence. At the same time this set of words can help avoid the more frequent interferences.

EuroComRom also has miniportraits (minigrammars) of the different languages that systematize the linguistic knowledge activated with the help of the sieves and complement it strategically. In that way, learners can go more deeply into the mastery of the language or languages they are most interested in. In these minigrammars, as well as an introduction with data about the geographical distribution, the speakers, the historical evolution or the dialectal varieties, learners can find a description of the characteristics of the language (mainly the ones related to pronunciation, the signs and the structure of the words). At the end of the characterization of each language, there is also a minivocabulary classified by grammatical categories, in which the 400 most frequent words are presented systematically: numbers, articles, prepositions, the most important nouns, adjectives, conjunctions, pronouns, place, time and quantity adverbs, and the twenty most frequent verbs with the regular and irregular forms. On the one hand, the words with which correspondences have been obtained by means of the sieves are set out in orderly fashion, and on the other the specific profile words of each language are added, since they are systematically important. In a final alphabetical compilation, the structurally most important words and the most frequent ones (which make up 50-60\% of any standard text) in each language appear. 
The miniportraits have been deliberately conceived in concentrated form, since the idea is that with a minimum investment of learning (a dozen pages per language) maximum yield for the comprehension of written texts is obtained. With this concentrate of information students have a sound base for developing receptive competence, which they can soon increase with intensive and gradually diversified reading of the languages chosen.

\section{CONCLUSION}

The language learning methods that focus on intercomprehension offer a feasible way of achieving receptive competences in different languages simultaneously. The EuroComRom method starts from a conviction that learning reading comprehension in the other Romance languages is relatively easy and fast due to the kinship that exists between them. It shows that from the outset a speaker of a Romance language has a sum of previous knowledge that makes learning easier and quicker. Moreover, since it is a method based on transferential strategies used by the autonomous learner, it improves the general language learning capacity through comparison of languages, the establishment of grammatical hypotheses, deduction, and analogy. EuroComRom has been conceived as a necessary complement to the available European language teaching systems. Most European schools aim to teach many pupils (with different results) one foreign language (usually English) and in some cases even a second one (German, Spanish, French or Italian). But this is a difficult way to achieve multilingualism that takes into account the linguistic diversity of Europe and leads to a real European language competence. The proposal therefore has to be understood as a complement to the conventional provision of language training, but it can also serve as an initiative for a reform of language teaching that will make learning easier.

In the new sociolinguistic context of the contemporary world, where the exponential expansion of the relations between different language groups involves for many people the need to overcome monolingualism, intercomprehension, from the perspective of both learning methodologies and forms of communication, can be a fundamental strategy. First, because it is a realistic option for generally extending (receptive) multilingualism, and thus making intercommunication easier without the need to belittle language diversity. Second, because it is a radical attack on the monolingual ideology that proposes the imposition of a single language as one of the indispensable conditions for the progress of society (Moreno Cabrera 80). 
From the point of view of Catalan, the option of interlinguistic communication by means of intercomprehension means a possibility of establishing more egalitarian relations with the neighboring languages, both in Europe and in Spain. In the case of Europe, the defense of multilingualism seems to have been clearly accepted, and thus support is being given to the different strategies that promote intercomprehension. Now all that is needed is to avoid lapsing into oligoglossia. As far as Spain is concerned, the coexistence of different languages (Spanish, Catalan, Basque, and Galician), with widely differeńt statuses, is still far from egalitarian. Since the democratic transformation of the state, Catalan, Basque, and Galician have been co-official in their respective autonomous communities, whereas Spanish is official throughout the state and, moreover, has the status of common language. ${ }^{8}$ And although the transition from nothing to coofficial has been a huge step forward for those languages, over the three decades of democracy little has been done to promote the coexistence on equal terms of the different language communities of Spain and their knowledge of one another. Indeed, it seems that there is a clear interest in defending state monolingualism and overlooking (if not preventing) the promotion of knowledge of languages other than Spanish. Only in that way can one understand the difficulties and the obstacles that still remain for the citizen of a particular autonomous community to have access to the television channels of another, or the fact that there are fewer possibilities of learning Catalan at university in Spain (excluding, of course, the Catalan-speaking areas) than in other European countries. For that reason, a strategy like EuroComRom can be highly positive in Spain to achieve the full coexistence of the language communities that make it up.

ESTEVE CLUA UNIVERSITAT POMPEU FABRA

${ }^{8}$ Moreno Cabrera (45) points out that it is usual to use this concept to hide or deny the multilingual character of a community. As an example, he puts the case of Switzerland, which is considered multilingual, as opposed to Spain, since the former does not have a common language whereas the larter does. The fact that a particular territory has a language understood by the majority of the population does not mean that it is everyone's, that there is no multilingualism. 


\section{WORKS CITED}

BASTARDAS, Albert. "Política lingüística mundial a l'era de la globalització: diversitat i intercommunicació des de la perspectiva de la "complexitat." Noves SL. Revista de Sociolingü̈stica (Summer 2002): I-I4. Io March 2002 <http://www6.gencat.net/llengcat/noves/ hmozestiu/ metodologia/bastardas.pdf >.

-. Cap a una sostenibilitat lingüústica. Barcelona: CETC, Angle, 2005.

Clua, Esteve, Pilar Estelrich, Horst G. Klein, and Tilbert D. STEGMAnN. Euro ComRom - Els set sedassos. Aprendre a llegir les llengües romàniques simultaniament. Aachen: Shaker, 2003.

COUNCIL OF EUROPE. Common European Framework of Reference for Languages: Learning, Teaching, Assessment. Cambridge: Cambridge UP, 2001.

Eco, Umberto. La ricerca della lingua perfetta. Rome, Bari: Laterza, I993.

GaLinSKa-INACIO, Iwona, Anna RANDAK, Horst G. KleIN, and Tilbert D. STEGMANN. Euro ComRom: Siedem filtróz: Jak od razu czytac teksty w jezykach romanskich. Aachen: Shaker, 2004

Giudicetti, Gian P., Constantino C. M. Maeder, Horst G. Klein, and Tilbert D. STEGMANN. EuroComRom - I sette setacci: Impara a leggere le lingue romanze. Aachen: Shaker, 2002.

GötTsCHe, Katja, Elke DA Silva, Horst G. KleIN, and Tilbert D. STEGMANN, EuroComRom - Os sete passadores. Saber ler todas as linguas românicas jä. Aachen: Shaker, 2003.

KISCHEL, Gerhard. EuroCom - Mebrsprachiges Europa durch Intercomprhension in Sprachfamilien. Tagungsband des intemationalen Facbkongresses zum Europäischen Jahr der Sprachen zoor. Hagen, gro November zoor. Aachen: Shaker, 2002.

KleIN, Horst G., and Tilbert D. Stegmann. EuroComRom - Die sieben Siebe: Romanische Sprachen sofort lesen Könen. Aachen: Shaker, 2000.

Martín, Ernesto, Esteve Clua, Horst G. Klein, and Tilbert D. STEGMANN. EuroComRom - Los siete tamices. Un fácil aprendizaje de la lectura en todas las lenguas románicas. Aachen: Shaker, 2005 .

MCCann, William J., Horst G. KleIn, and Tilbert D. StegmanN. EuroComRom. The Seven Sieves: How to Read all the Romance Languages Right Away. Aachen: Shaker, 2003.

Meissner, Franz Joseph, Claude Meisner, Horst G. KieIN, and Tilbert D. STEGMANN. EuroComRom: Les sept tamis: live les langues romanes dès le départ; avec une esquisse de la didactique de l'eurocomprébension. Aachen: Shaker, 2004. 
Moreno Cabrera, Juan Carlos. De Babel a Pentecostés. Manifiesto plurilingüista. Barcelona: Horsori, 2006.

ReINHeimer, Sanda, Horst G. Klein, and Tilbert D. StegmanN. EuroComRom - Şapte Site: Sa citim şi sa intelegem simultan limbile romanice. Bucharest: Cavallioti, 200I. 